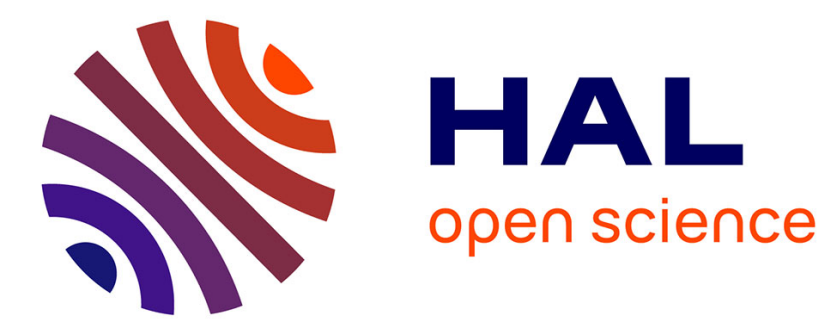

\title{
Outer Space, Expansive Sustainable Development, and the Future of the Environmental Humanities
}

\author{
Brad Samuel Tabas
}

\section{To cite this version:}

Brad Samuel Tabas. Outer Space, Expansive Sustainable Development, and the Future of the Environmental Humanities. 2021, 10.20935/al120 . hal-03150750

\author{
HAL Id: hal-03150750 \\ https://hal.science/hal-03150750
}

Submitted on 9 Mar 2021

HAL is a multi-disciplinary open access archive for the deposit and dissemination of scientific research documents, whether they are published or not. The documents may come from teaching and research institutions in France or abroad, or from public or private research centers.
L'archive ouverte pluridisciplinaire HAL, est destinée au dépôt et à la diffusion de documents scientifiques de niveau recherche, publiés ou non, émanant des établissements d'enseignement et de recherche français ou étrangers, des laboratoires publics ou privés. 


\title{
ACADEMIA $\mid$ Letters
}

\section{Outer Space, Expansive Sustainable Development, and the Future of the Environmental Humanities}

\author{
Brad Tabas
}

What does it mean to be live sustainably?

Work within the environmental humanities assumes that sustainable development will happen on planet Earth. Sustainability is associated with respecting the limits of the planet, the transition away from fossil fuels, the escape from the growth mindset, and the protection of biodiversity. However, a new wave of space expansion advocates is using sustainable development in an alternative way. "Sustainable" is used to refer to self-perpetuating private economic activities off-world. "Sustainable" is also employed to refer to permanent space habitats that rely on the harvest of local (but unrenewable) space resources. Finally, "sustainable" is used to describe forms of extra-terrestrial extractivism—e.g., strip-mining asteroids-which would be carried out with the aim of offsetting Earth-side resource deficits. From the point of view of traditional understandings of sustainable development, these uses of the term "sustainable" are perverse. By expanding horizons of the world out beyond the Earth-by becoming post-planetary - expansive sustainability subsumes a whole range of current practicesconsumerism, extensive reliance on unrenewable resources, unending population growth, and even unbridled pollution —within the limits of what is judged "sustainable." Post-planetary or expansive sustainability seems to legitimate the sustainability of the unsustainable.

Nevertheless, expansive sustainability seems to meet the Brundtland commission's definition of sustainable development: "development which meets the needs of current generations without compromising the ability of future generations to meet their own needs." This is in part because expansive sustainability, like Earth-bounded sustainability, takes into account the long-term future: "deep time." Yet expansive sustainability differs sharply from traditional sustainability with respect to the location of those future generations. Earth-bound advocates of sustainability have always imagined the future in terms of intensification. In other words,

Academia Letters, January 2021 @2021 by Academia Inc. — Open Access — Distributed under CC BY 4.0

Corresponding Author: Brad Tabas, brad.tabas@ensta-bretagne.fr

Citation: Tabas, B. (2021). Outer Space, Expansive Sustainable Development, and the Future of the Environmental Humanities. Academia Letters, Article 120. https://doi.org/10.20935/AL120. 
sustainable development will ecologically optimize the forms taken by human lives with respect to the present horizons of what is imagined to be the world-namely the planet. To the contrary, the post-planetary understanding of sustainability is expansive. It embraces the idea that the horizons of the future world will differ from those of the present moment. These different pictures of the future as it relates to the expansion of inhabitable space correlate with different understandings of the past and present. From the point of view of Earth-bound sustainability, humankind once lived, and in some locales still does live, in a sustainable manner. What we need to do is collectively find a way of rediscovering or inventing a future form of sustainable existence. From the point of view of the advocates of post-planetary sustainability, what is age-old is the human propensity to wander. From the dawn of time, humans have left behind old habitats in search of new and more promising territories.

There are, of course, major differences between emigrating from Europe to America and colonizing the solar system. Human bodies have not evolved to live in outer space. They have co-evolved - and mutually depend upon — the other members of their biotic community here on Earth. To survive in space, expansive sustainability will require that humanity become post-human. Future dwellers of the expanse will have new bodies and new relationships to their bodies. That said, advocates of post-planetary sustainability aim to perpetuate forms of life and ways of viewing the world that are characteristic of how humans imagine themselves today. Stephanie Le Menager has described us as "living oil," as beings whose cultured forms of existence are inseparable from the dominant-and unsustainable-source of energy which powers our civilization. The post-planetary dream of colonizing Titan, a moon of Saturn covered with hydrocarbon lakes, is clearly entangled with the fact that there, human beings might be able to continue living as oil, but without the catastrophic consequences that will follow by remaining on Earth.

It is crucial to insist that both the expansive and the intensive sustainable development trajectories are real. Real not in the sense that either a sustainable future in space or on Earth has been achieved-neither are close to real in that sense. But real in the sense that both are current anticipations, actual projects towards which multiple individuals are already collectively engaged. Processing this is anything but obvious-particularly for environmental humanities scholars. One common response to expansive sustainability has been to dismiss it as science fiction-i.e. as science fantasy. Yet this objection is weak. It is flawed because it overlooks the very real advances that have been made towards the conquest of space. The ISS, the first semi-permanent human habitat in space is currently celebrating its 30th anniversary. It is more likely than not that a permanent base on the Moon, and potentially one on Mars, will have been established by 2050. The economic expansion of the human impact zone, the extractive zone of capitalism, is already post-planetary. Governments-including the United States, China,

Academia Letters, January 2021 @2021 by Academia Inc. — Open Access — Distributed under CC BY 4.0

Corresponding Author: Brad Tabas, brad.tabas@ensta-bretagne.fr

Citation: Tabas, B. (2021). Outer Space, Expansive Sustainable Development, and the Future of the Environmental Humanities. Academia Letters, Article 120. https://doi.org/10.20935/AL120. 
Japan, the UAE, and the EU—are investing heavily in providing legal, military and financial support for an already booming space economy. Private individuals-let by multi-billionaires Jeff Bezos and Elon Musk-are investing heavily in innovative space industry projects. Commercial space mining operations are still a fiction, but the construction of the infrastructure that will make these and other space ventures possible is well underway. The failure to reckon with expansive sustainability is also complicit in a generalized ignorance among environmental humanities scholars with respect to the very real environmental impacts already being caused by space expansionism, for example, the growing problem of space junk. Yet where this objection is perhaps most flawed has to do with the status of Earth-bound sustainable futures. To deride expansive sustainability as fiction suggests that it is comparatively unrealistic compared to imagining sustainable futures on Earth. Yet the current obsession with dark and catastrophist rhetoric within the environmental humanities demonstrates the contrary. It is very difficult to imagine any sustainable human future on Earth that does not resort to fantasy or to first presupposing a mass die-off of a good portion of the Earth's population. Needless to say, acknowledging these objections in no way means that sustainable human civilization will soon be flourishing in outer space. Nor does it mean that environmental humanities scholars should uncritically embrace space expansionism. It does mean, however, that it is high time to recognize that our currently unsustainable civilization is already expanding to outer space.

Expansive sustainability issues in a new challenge for scholars in the environmental humanities. We must begin thinking critically about what expansive sustainability means, has meant, and will mean. This will demand embracing more fully outer space within the conceptual ecosystem of the environmental humanities, even if that embrace involves rejecting expansive solutions to our current problems. Up until the present, the environmental humanities have largely been defined in opposition to ignorance and climate skepticism. Yet in light of discourses advocating for expansive sustainability, this positioning may need to be revised and re-evaluated. Advocates of post-planetary sustainability are in no way skeptical about the dangers facing the planet or about the limits of planetary resources-they are only skeptical about the solutions available on Earth. For this reason, the alarmism typical of contemporary environmental discourse bolsters, rather than opposes, those seeking to pitch post-planetary sustainability. The worse and more unimaginable a flourishing future on Earth appears, the more alluring the siren call of space, and the more complicit current environmental discourses are in fueling expansionist projects. At this point, it is nearly impossible to say what this will mean for the long-term future of the humankind and its environments. Yet what is irrefutable is that the discourses of post-planetary sustainability should and do matter for the present and future of the environmental humanities.

One example of this is with respect to the discipline's own past. The experience of see-

Academia Letters, January 2021 @2021 by Academia Inc. — Open Access — Distributed under CC BY 4.0

Corresponding Author: Brad Tabas, brad.tabas@ensta-bretagne.fr

Citation: Tabas, B. (2021). Outer Space, Expansive Sustainable Development, and the Future of the Environmental Humanities. Academia Letters, Article 120. https://doi.org/10.20935/AL120. 
ing Earth from space has long been described as a foundational moment in the history of environmental consciousness and the sustainability movement. In his recent film memoir, A Life on Our Planet, a very sage David Attenborough reminisces about how the sight of Earth from space "completely changed the mindset of the population, the human population of the world," bringing home the idea that "Our home was not limitless. That there was an edge to our existence." Yet this statement is true and untrue. Seeing the whole Earth did not mean the same thing to everyone. To the contrary, it was a moment of divergence in which two competing visions of the sustainable were born. One portion of the population saw the Earth framed by blackness; another portion of the population saw the Earth yet attended to the astronaut, the being out there, real at the edge of an extending human habitat. Dark my words may seem to many environmental humanities scholars. Indeed, it may be right to argue that we should never embrace expansive sustainability. It would be foolish, however, to remain unconcerned about the relevance of the world beyond the planet in the future of the environmental humanities.

\section{Bibliography}

2020. David Attenborough: A Life on Our Planet. Directed by David Attenborough. Performed by David Attenborough.

Brundtland, Gro Harlem, M. Khalid, S. Agnelli, S. Al-Athel, and B. J. N. Y. Chidzero. 1987. Our Common Future. The World Commission on Environment and Development, Oxofrd: Oxford University Press.

LeMenager, Stephanie. 2014. Living Oil: Petroleum Culture in the American Century. New York: Oxford University Press. 